\title{
Model of Container Terminal Competition with Game Theory Approach
}

\author{
$1^{\text {st }}$ Achmad Mustakim, $2^{\text {nd }}$ Tri Achmadi, $3^{\text {rd }}$ I.G.N. Sumanta Buana, $4^{\text {th }}$ Irwan Tri Yunianto, $5^{\text {th }}$ Eka \\ Wahyu Ardhi, 6,7 $7^{\text {th }}$ Marchela Yaniarsih, Alwi Sina Khaqiqi \\ \{mustakimachmad@gmail.com\}
}

Department of Marine Transportation Engineering Institut Teknologi Sepuluh Nopember, Indonesia

\begin{abstract}
Along with rapid economic growth in Indonesia, Container throughput of Indonesia's Port also increasing. The container throughput of Tanjung Priok decrease on average $7.8 \% 2012$ - 2015. The CAGR of container throughput $2015-2016$ is $9.5 \%$. PT. JICT and TPK Koja are located at Tanjung Priok Port so that the terminal location is close together, so the hinterlands between JICT and TPK Koja are the same. The rapidly growing container trends encourage the development of container terminals to compete in providing services and facilities. For example JICT is superior in berth length, it has a pier length of 1,640 m while the Koja TPK only has a pier length of $650 \mathrm{~m}$ then In terms of JICT container yard capacity is superior that is equal to 39,884 TEUs while Koja TPK is only 15,456 TEUs, in terms of the water depth JICT and TPK Koja have 14 mLWS. The creation of inter-port competition can be marked by differences in the number of International containers throughput. in 2014 JICT has 2,372,470 TEUs international container throughput and KSO Koja TPK has 587,712 TEUs international container throughput. In 2015 JICT's throughput is decrease. The throughput is 2,223,179 while the KSO TPK Koja increased to 648,373 TEUs. In 2016 JICT's throughput decreases again to be 2,144,398 TEUs and for KSO TPK Koja also decline to be 561,895 TEUs. This research is conducted to determine the port competition with game theory approach. The result JICT has 53\% market share and TPK Koja has 47\%.
\end{abstract}

Keywords. Competition, Container Terminal, Game Theory

\section{Introduction}

Along with rapid economic growth, in Indonesia there has also been an increase in the volume of containers. The largest volume of container throughput in Indonesia is the Tanjung Priok Port throughput. Tanjung Priok Port is the number one busiest port in Indonesia. Tanjung Priok Port container throughput decreases $7.8 \%$ on average annually and in 2015- 
2016 Tanjung Priok Port throughput increased by $9.5 \%$. The container throughput of Tanjung Priok Port can be seen at figure 1

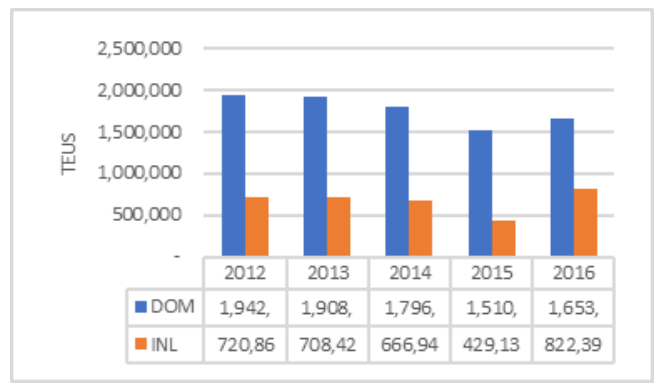

Fig. 1. Container troughput of Tanjung Priok Port

Source: www.priokport.co.id

Tanjung Priok port has many container terminals. The terminals are Jakarta International Container Terminal (JICT), KSO Terminal Petikemas Koja (Koja), Terminal Petikemas Indonesia and New Priok Container Terminal (NPCT1). JICT and Koja are located in Tanjung Priok Port and the locations are close from each other. So that the hinterlands of those terminal are same. The location of JICT and Koja can be seen in figure 2 .

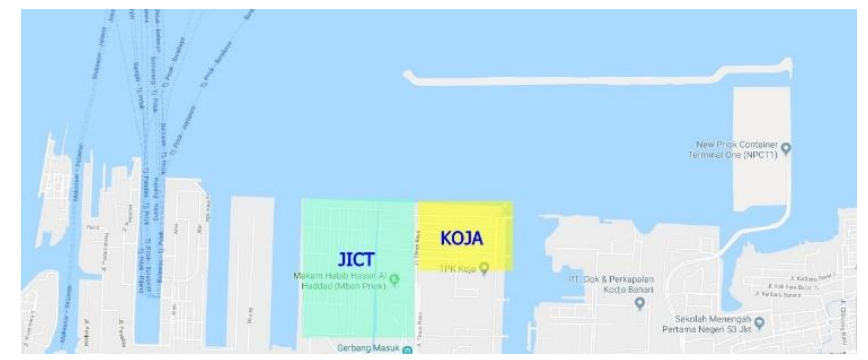

Fig. 2. Layout Tanjung Priok Port

Tariff, facility, and administration performance become key performance indicator to compete in Port Business. So that every Terminal Operator needs to make appropriate strategy to compete. The most important is The terminal operator needs to understand the pay-off of each strategy. The pay-off of each strategy represented by the market share of the throughput each terminal.

JICT and Koja compete for the container throughput market. This research models the container terminal competition. This research conducts the game theory as the approach. The objective of this research is make container terminal competition model with game theory approach. Then the market share of each Terminal can be known.

One of the input to build the model is terminal facilities. JICT is superior in berth length, it has a pier length of $1,640 \mathrm{~m}$ while the Koja only has a pier length of $650 \mathrm{~m}$ then In terms of JICT container yard capacity is superior that is equal to 39,884 TEUs while Koja TPK is only 15,456 TEUs, in terms of the water depth JICT and TPK Koja have $14 \mathrm{mLWS}$. The creation 
of inter-port competition can be marked by differences in the number of International containers throughput. in 2014 JICT has 2,372,470 TEUs international container throughput and KSO Koja TPK has 587,712 TEUs international container throughput. In 2015 JICT's throughput is decrease. The throughput is 2,223,179 while the KSO TPK Koja increased to 648,373 TEUs. In 2016 JICT's throughput decreases again to be 2,144,398 TEUs and for KSO TPK Koja also decline to be 561,895 TEUs

This model can help the decision maker of port operator to make right decision.

\section{Literature Review}

There are 3 kinds of terminal operator competition. They are interport, intraport and intra terminal competition. Interport competition is occurred when one region there are two or more for one commodity. Intra Port competition is occurred when there are two or more terminal in one port and compete for same commodity. Intra-terminal competition is occurred when in one terminal there are two or more stevedoring company.

Port competition is influenced by many factors, such as: location, infrastructure of hinterland, industrialization rate, government regulation and performance of port [1]. Container terminal competitiveness is determined by 6 criteria. Those criteria are Location, port infrastructure, connectivity, port management, port administration and port cost [2] According to George Kobina Van Dyck and Hawa Mohammed Ismael port competitiveness was determined by 6 criteria, such as throughput, port location, terminal operator efficiency, port infrastructure, port costs, political stability in the port area [3]

According to Yeo Gi Tae, the competitiveness of the container terminal is determined by 7 criteria, such as: port service, conditions around the port area (hinterland), dock availability, comfort namely dock depth and groove depth, logistics costs, regional economic centers, connectivity. [4]

Game theory is a collection of analytical tools designed to help understand the phenomena observed when decision makers interact [5]. Game theory is also a formal study of conflict and cooperation in decision making where several players must make choices that have the potential to influence the interests of other players [6]. The game theory concept provides language to formulate, compile and analyze and understand strategic scenarios

Research conducted by Besti Pratiwi discussed the competition between domestic container terminals at Tanjung Perak Port, namely Terminal Services Diamond Terminal (BJTI), Surabaya Container Terminal (TPS), Terminal Nilam and Teluk Lamong Terminal (TTL). Competition can occur because the location of the terminal is close to each other so that it has a similar hinterland. [6]

Research on competition in the shipping business discussed by Bagus Prasetyo wibowo is based on the increasingly tight growth of new shipping companies. Each shipping company competes in competing for customers to get as much profit as possible. Unfair competition occurs in the business competition of PT. A and PT. B on Surabaya-Banjarmasin Surabaya shipping route. Tariff determination is the key strategy to win the competition [7]. In this research game theory is used to formulate the competition situation of shipping company 


\section{Methodology}

The game theory model is done by this steps:

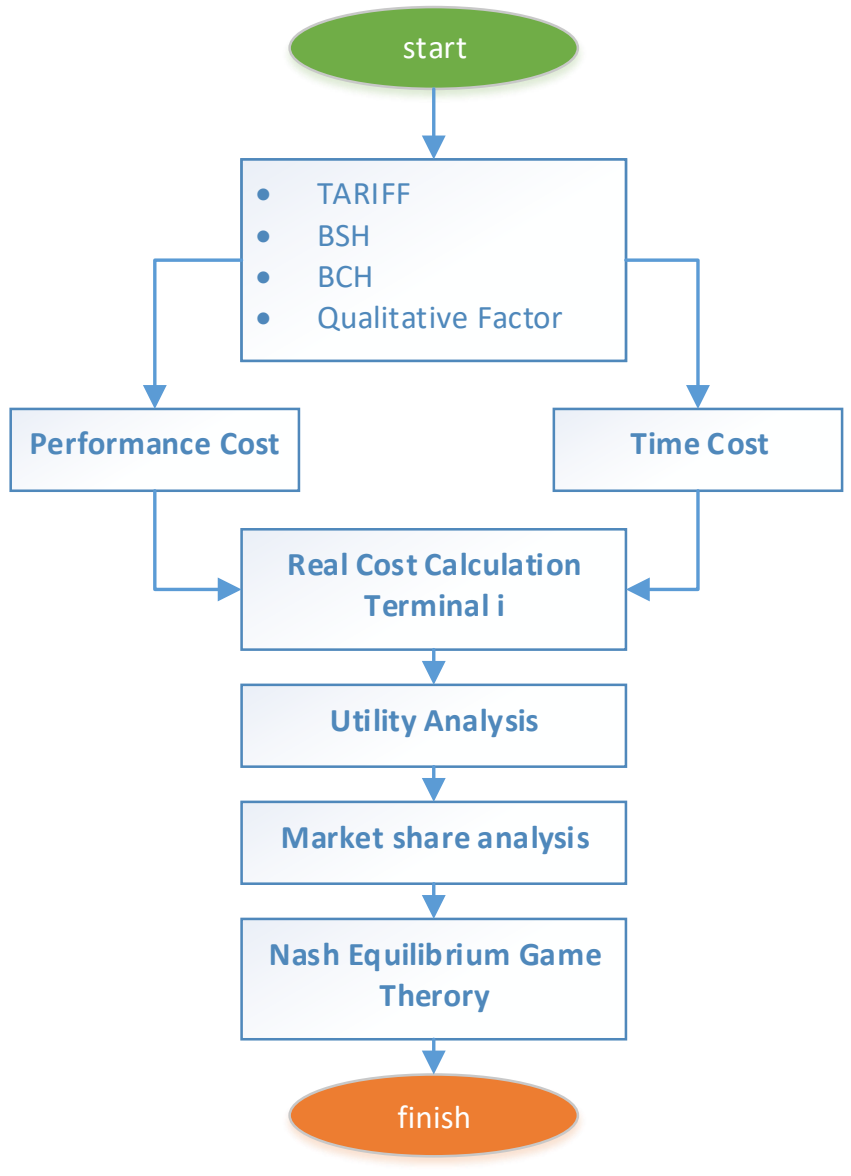

Fig. 3. Methodology of Research

\section{Result \& Discussion}

This research discusses about the competition of international container terminal in Tanjung Priok port especially between JICT and Koja. JICT has throughput 1,610,809 TEUs and Koja has throughput 1,092,665 TEUs. Total throughput is 2,703,473 TEUs.

Factors are used for container terminal competition for this research are:

\subsection{Tariff}

Tariffs for those two terminal are: 
Table 1. Stevedoring tariffs

\begin{tabular}{cccl}
\hline \multicolumn{2}{c}{ 20'$^{\prime}$} & \multicolumn{2}{c}{$\mathbf{4 0}^{\prime}$} \\
\hline Full (IDR) & $\begin{array}{c}\text { Empty } \\
\text { (IDR) }\end{array}$ & $\begin{array}{c}\text { Full } \\
\text { (IDR) }\end{array}$ & $\begin{array}{l}\text { Empty } \\
\text { (IDR) }\end{array}$ \\
$1,199,101$ & 899,326 & $1,798,652$ & $1,348,916$
\end{tabular}

Terminals tariff that used is IDR Full container 20 feet: IDR 1,199,101,-

\subsection{Loading and unloading productivity}

Loading and unloading is represented by BSH (Berth Ship Hours)

Table 2. Berth Ship Hour (BSH)

\begin{tabular}{lrr}
\hline & $\begin{array}{l}\text { JICT } \\
\text { (box/jam) }\end{array}$ & \multicolumn{1}{l}{$\begin{array}{l}\text { KOJA } \\
\text { (box/jam) }\end{array}$} \\
\hline BSH (move/hours) & 59.30 & 58.36 \\
\hline
\end{tabular}

\subsection{Efficiency}

Efficiency is represented by BCH (Berth Container Hours)

Table 3. Berth Crane Hour (BCH)

\begin{tabular}{lll}
\hline & $\begin{array}{l}\text { JICT } \\
\text { (box/hour) }\end{array}$ & $\begin{array}{l}\text { KOJA } \\
\text { (box/hour) }\end{array}$ \\
\hline BCH & 25 & 22 \\
Capacity & 27 & 27 \\
\hline
\end{tabular}

\subsection{Qualitative Factor}

Qualitative factor is represented by IT (Idle Time)

These are the IT of JICT and KOJA:

Table 4. Idle Time (IT) Terminal

\begin{tabular}{|c|c|c|}
\hline & JICT & KOJA \\
\hline IT (hour) & 3.30 & 2.61 \\
\hline
\end{tabular}

\subsection{Normalization}

Because each factors are heterogeneous so that each factor need to be normalize. So the number can be homogeneous with range $0-1$. The normalize number each factor can be see below:

Table 5. Normalize number each factor

\begin{tabular}{|c|c|c|}
\hline Factors & JICT & KOJA \\
\hline Tariff & 1 & 1 \\
\hline $\begin{array}{l}\text { Loading and unloading } \\
\text { productivity }\end{array}$ & 0.65 & 0.62 \\
\hline
\end{tabular}




\begin{tabular}{lll} 
Efficiency & 0.55 & 0.27 \\
Qualitative Factor & 0.34 & 0.48 \\
\hline
\end{tabular}

4.6 Cost Analysis

4.6.1 Real Cost

Real cost is the cost that shipping company must paid without the profit of container terminal. [9]:

Where:

$$
R C=P+T C-P C
$$

$R C=$ Real Cost

$T C=$ Time Cost (Stevedoring cost)

$P C=$ Perfomance Cost Terminal

\subsubsection{Time Cost (TC)}

Where:

$$
T C=P x \frac{F B S H}{F P}
$$

$F B S H=$ Normalize number Efficiency

$F P=$ Normalize number Tariff

\subsubsection{Perfomance Cost (PC)}

Where:

$$
\begin{aligned}
P C & =B S H+I T \\
B S H & =F B S H x \frac{p}{p P} \\
I T & =F I T x_{F p}^{\frac{p}{p}}
\end{aligned}
$$

$F I T=$ Normalize number of Qualitative factor

So the real cost of those two terminala are:

Table 6. Real Cost Calculation

\begin{tabular}{lrrrr}
\hline & \multicolumn{1}{c}{ JICT } & \multicolumn{2}{c}{ KOJA } \\
\hline P & Rp & $1,199,101$ & Rp & $1,199,101$ \\
TC & & 785,218 & & 749,013 \\
BSH & & 654,055 & & 329,746 \\
IT & & 406,524 & & 573,518 \\
PC & Rp $1,060,579.30$ & Rp & $903,263.01$ \\
RC & Rp & $923,739.45$ & Rp & $1,044,850.97$ \\
\hline
\end{tabular}

From table above is known that Real Cost of JICT is less than KOJA

\subsubsection{Utility Analysis}

Utility of container terminal represents the attractiveness of the terminal. The utility of terminal uses equation below [9]: 


$$
\mathrm{Ui}=\frac{1}{\frac{R C i}{R C b}}
$$

Where:

$R C i=$ Real Cost terminal i

$R C_{b}=$ Real Cost terminal benchmark

The terminal benchmark is Koja. So the result can be seen below:

Table 7. Utility Value of Terminal

\begin{tabular}{lrrr}
\hline & JICT & KOJA & \\
\hline $\mathrm{U} i$ & 1.13 & & 1
\end{tabular}

Market share analysis

Market share calculation represent the throughput of each terminal. The formula for market share is [8]:

Where:

$$
\mathrm{M}_{\mathrm{i}}=\frac{e^{U i}}{\sum_{Y=1}^{T=n} e^{U T}}
$$

$M_{i}=$ Market Share terminal i

$n=$ terminal ke-n

The results can be seen on the table below:

Table 8. Result of Market Share

\begin{tabular}{lrr}
\hline & \multicolumn{1}{c}{ JICT } & \multicolumn{1}{c}{ KOJA } \\
\hline $\mathrm{U}$ & 1.13 & 1 \\
$\mathrm{e}$ & $4.18391 \mathrm{E}-07$ & $3.69895 \mathrm{E}-07$ \\
& 4.18 & 3.69 \\
$\mathrm{Uj}$ & 7.87 & \\
$\mathrm{E}$ & $53 \%$ & $47 \%$
\end{tabular}

From the table above can be seen JICT has 53\% market share and KOJA has $47 \%$ market share. It means JICT is superior to KOJA

\section{Conclusion}

From this research can be concluded:

5.1 Game theory approach can be used to model the container terminal competition. The model is : $\mathrm{f}$ (Tariff, BSH, BCH, CAPACITY, IT)

5.2 Market share of JICT is $53 \%$ and KOJA is $47 \%$. And this is the nash equilibrium of game theory for terminal competition.

5.3 JICT is superior from KOJA

5.4 This model can be used to simulate the strategy of terminal operator, so that they will know the pay-off of the strategy. 


\section{References}

[1] H. Meersman, E. V. d. Voorde dan T. Vanelslander, Port Competition Revisited, 2010.

[2] H. Luo, "An Analysis of Port Competitiveness through User's Perception Measurement," Erasmus University, Rotterdam, 2013.

[3] G. K. V. Dyck dan H. M. Ismael, "Multicriteria of Port Competitiveness in West Africa Using Analytic Hierarchy Process," American Journal of Industrial and Business Management, pp. 440-441, 2015.

[4] Y. G. Tae, "Measuring The Competitiveness of Container Ports: Logistician's Persepectives," Competitiveness of Container Ports, p. 458, 2011.

[5] M. J. Osborne dan A. Rubinstein, A Course in Game Theory, London: The MIT Press, 2011.

[6] T. L. Turocy, Game Theory, 2001.

[7] B. Pratiwi, "Tugas Akhir," Analisis Daya Saing Antar Terminal Petikemas Dalam Suatu Wilayah: Studi Kasus Terminal Petikemas Wilayah Surabaya, 2017.

[8] B. P. Widodo, "Tugas Akhir," Pengembangan Model Persaingan Penentuan Tarif Angkut Kapal dengan Metode Game Theory, 2014.

[9] T. A. Amin, Kompetisi Antar Terminal Peti Kemas Studi Kasus Pelabuhan Tanjung Priok, 2018.

[10] S. J. Veldman dan E. H. Buckmann, "Maritime Economics \& Logistics," A Model on Container Port Competition: An Application for the West European Container Hub-Ports, p. 7, 2003.

[11] B. M. Ju, A Game Theoretic Approach to Analyzing Container Transhipment Port Competition, Singapore, 2013. 